Jurnal Keperawatan Silampari

Volume 4, Nomor 1, Desember 2020

e-ISSN: 2581-1975

p-ISSN: 2597-7482

DOI: https://doi.org/10.31539/jks.v4i1.1450

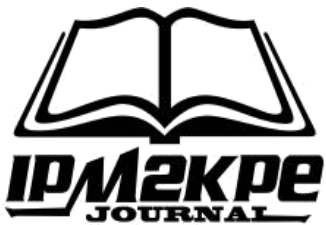

\title{
ANALISIS LACTAT DEHYDROGENASE DALAM SERUM DARAH MENGGUNAKAN SENTRIFUGASI
}

\author{
Rosnita Sebayang ${ }^{1}$, Yuana Idawati ${ }^{2}$, Hotman Sinaga ${ }^{3}$ \\ Uiversitas Katolik Musi Charitas ${ }^{1,2,3}$ \\ ros.sebayang@gmail.com ${ }^{1}$
}

\begin{abstract}
ABSTRAK
Penelitian ini bertujuan untuk memperpendek waktu pelayanan laboratorium dengan cara mempersingkat waktu sentrifuse serta memperoleh serum sebagai bahan pemeriksaan. Metode penelitian yang digunakan adalah penelitian pre-eksperimental. Hasil penelitian menunjukkan bahwa rata-rata LDH pada kelompok darah yang disentrifugasi $3000 \mathrm{rpm} 5$ menit sebesar 309,9 U/L dan 306,4 U/L yang disentrifugasi $4400 \mathrm{rpm} 3$ menit pada kelompok darah. Simpulan, tidak terdapat perbedaan kadar LDH dalam serum dari darah yang disentrifugasi $3000 \mathrm{rpm}$ selama 5 menit dan 4400 rpm selama 3 menit
\end{abstract}

Kata Kunci : Centrifugation, Lactat Dehydrogenase, TAT

\section{ABSTRACT}

This study shortens the laboratory service time by shortening the centrifuge time and obtaining serum as an examination material. The research method used was preexperimental research. The results showed that the average $L D H$ in the blood group centrifuged $3000 \mathrm{rpm} 5$ minutes was $309.9 \mathrm{U} / \mathrm{L}$ and $306.4 \mathrm{U} / \mathrm{L}$ centrifuged 4400 rpm 3 minutes in the blood group. In conclusion, there is no difference in serum LDH levels from blood centrifuged at 3000 rpm for 5 minutes and 4400 rpm for 3 minutes.

Keywords: Centrifugation, Lactate Dehydrogenase, TAT

\section{PENDAHULUAN}

Menurut PMK No. 43 tahun 2013 mengatakan bahwa pemeriksaan laboratorium klinik terdiri dari beberapa jenis pemeriksaan yaitu pemeriksaan hematologi, pemeriksaan mikrobiologi, pemeriksaan parasitologi, pemeriksaan virologi, pemeriksaan kimia klinik, pemeriksaan imunologi dan pemeriksaan patologi anatomi. Pemeriksaan kimia klinik adalah suatu kegiatan pemeriksaan yang berhubungan dengan spesimen klinik. Salah satu pemeriksaan kimia klinik adalah pemeriksaan Lactat Dehidrogenase (LDH) yang umum untuk pemeriksaan kelainan jantung (Cadamuro et al., 2018).

Menurut data World Health Organization (WHO) dalam Info Datin Kemenkes RI (2019) menyebutkan bahwa 17,5 juta orang (31\%) dari 56,5 juta orang yang meninggal dunia disebabkan penyakit jantung. Dari seluruh kematian akibat penyakit jantung diantaranya 7,4 juta orang $(42,3 \%)$ disebabkan Penyakit Jantung Koroner (PJK). Kasus penyakit jantung berdasarkan diagnosis dokter sebesar $883.447(0,5 \%)$ sedangkan $2.650 .340(1,5 \%)$ diduga penyakit jantung. 
Pada kasus penyakit jantung untuk menegakkan diagnosisnya biasanya dilakukan pemeriksaan Elektrokardiogram (EKG) dan pemeriksaan laboratorium. Pemeriksaan laboratorium untuk penyakit jantung ada beberapa analit yang dikenal sebagai panel jantung yaitu LDH, AST, CK, CK-MB, Troponin I, Troponin T, ALT dan HBDH. Salah satu analit yang diperiksa pada kelainan jantung adalah LDH Laktat dehidrogenase (lactic dehidrogenase, $\mathrm{LDH}$ ) adalah enzim intraselular yang terdapat pada hampir semua sel yang bermetabolisme, dengan konsentrasi tertinggi ditemukan di jantung, otot rangka, hati, ginjal, otak dan sel darah merah (Ghaniet al ., 2016).

Aktivitas LDH pada semua sel tubuh terutama di dalam sitoplasma dalam jumlah yang bervariasi. Konsentrasi LDH pada beberapa jaringan dapat mencapai 500 kali kadar normal dalam serum. Oleh karena itu kerusakan jaringan yang kecil pun dapat menyebabkan peningkatan aktivitas LDH yang bermakna. Pada pemeriksaan LDH sampel pemeriksaan adalah serum atau plasma namun yang direkomendasi terutama serum.

Sentrifugasi merupakan suatu teknik pengendapan yang dilakukan untuk memisahkan endapan dari suatu suspensi Gressner \& Gressner (2017). Kecepatan tersebut dinyatakan dalam rpm (revolution per minute atau putaran per menit). Pemeriksaan laboratorium yang sensitif dan akurasi yang tinggi dapat mendeteksi $98 \%$ pasien pada saat diagnosis (Hermayanti \& Nursiloningrum, 2018).

Bila waktu pemutaran panjang akan menyebabkan naiknya suhu pada bahan yang diputar. Kenaikan suhu dapat menyebabkan sel-sel lisis atau analit yang akan diperiksa rusak (Lippi et al., 2018). Penelitian sebelumnya menyebutkan bahwa waktu sentrifugasi 4 menit dengan kecepatan $4122 \mathrm{rpm}$ dan 10 menit kecepatan $3783 \mathrm{rpm}$ untuk pemeriksaan LDH menunjukan tidak terdapat perbedaan yang signifikan $(\mathrm{P}>0,05$ untuk semua) (Magnette et al., 2016).

Faktor kecepatan dan waktu sentrifus memiliki hubungan yang berbanding terbalik berdasarkan persamaan gerak melingkar beraturan, sehingga semakin tinggi kecepatan sentrifugasi maka semakin sedikit waktu yang dibutuhkan sentrifus untuk memutar (EidLidt et al., 2019).

Salah satu faktor yang mempengaruhi kualitas serum adalah sentrifugasi. Sentrifugasi adalah teknik pemisahan cairan dari padatannya Pada penelitian ini, sentrifugasi digunakan untuk memisahkan cairan dari padatan sel darah sehingga diperoleh serum. Sentrifugasi merupakan langkah pertama pada hampir semua prosedur fraksionasi atau penguraian sel yang digunakan untuk memisahkan endapan dari suatu suspensi dengan ukuran yang jauh berbeda (Brassard et al., 2018). Perbedaan serum dan plasma yang berada di dalam sel tidak boleh keluar sel agar tidak terjadi hemolisis yang dapat mempengaruhi hasil pemeriksaan. Selain hemolisis, sampel lipemik dan ikhterik dapat mengganggu pembacaan pada spektrofotometer (Ramadhani et al., 2019).

Tanpa mengurangi kualitas serum maka dilakukan pengurangan waktu sentrifugasi karena pemeriksaan Laktat Dehydrogenase (LDH) yang berada pada jantung dan hati perlu penanganan cepat sehingga hasil pemeriksaan juga dibutuhkan cepat. Lalu yang bisa dilakukan adalah mengurangi waktu sentrifugasi akan memberi dampak yang baik bagi laboratorium (Brassard et al., 2018).

Sehubungan dengan pengurangan waktu maka akan di dapat juga manfaat lain dari aspek ekonomi yaitu penghematan listrik sehingga variable cost dari suatu laboratorium tersebut dapat berkurang. Berdasarkan KepMenKes RI No. 605 Tahun 2008, kebutuhan daya listrik suatu laboratorium kesehatan $120 \mathrm{kVA}$ untuk penerangan, AC, dan alat laboratorium. Menurut Tarif Tenaga Listrik PT. PLN (2017), golongan tarif dengan batas 
daya 6.600 VA sampai dengan $200 \mathrm{kVA}$ ialah Rp 1.467,28 per kWh. Pemeriksaan LDH di laboratorium dengan hitungan jumlah $\mathrm{kWh}$ adalah $9.960 \mathrm{kWh} /$ tahun, sehingga dana yang dapat dihemat per tahun adalah Rp 14.614.109,00.

Dampak pengurangan waktu sentrifugasi dapat memperlambat penurunan produktivitas atau kinerja sentrifus akibat penggunaan yang terlalu lama sehingga fungsi alat tersebut menurun. Selain itu, dapat memperpanjang penggunaan alat, menurunkan biaya perawatan sentrifus, mengurangi kerugian waktu ketika alat tidak berproduksi dan menurunkan biaya pengeluaran suku cadang alat (Schneider \& Alcalay, 2017).

Penelitian sebelumnya menjelaskan bahwa bisa menurunkan waktu dari 15 menit menjadi 7 dan 5 menit, namun pada penelitian ini saya akan membuat waktu hanya 3 menit dalam proses darah menjadi serum, tanpa mengurangi kualitas serum.

\section{METODE PENELITIAN}

Subjek penelitian adalah 30 mahasiswa DIV Analis Kesehatan Fakultas Ilmu Kesehatan UKMC yang memenuhi kriteria inklusi dan eksklusi kemudian diambil darah sebanyak 4 CC. Kemudian darah ditampung dalam 2 tabung bertutup merah (tabung clot) tabung pertama dan kedua didiamkan 30 menit lalu disentrifugasi dan dipisahkan serumnya. Selanjutnya dilakukan pemeriksaan LDH dalam serum dengan alat Byosistem Analyzer A15 dengan menggunakan metode IFCC yang dilakukan di laboratorium Balai Besar Laboratorium Kesehatan Palembang.

Jenis penelitian yang digunakan adalah penelitian pre-eksperimental. Penelitian ini dilakukan untuk melihat perbedaan kadar LDH menggunakan serum dari darah yang disentrifugasi dengan kecepatan $3000 \mathrm{rpm}$ selama 5 menit dan $4400 \mathrm{rpm}$ selama 3 menit. Metode pengambilan sampel adalah total sampling. Sampel yang digunakan adalah mahasiswa DIV Analis Kesehatan Fakultas Ilmu Kesehatan UKMC. Data hasil penelitian di uji dengan uji statistik Paired T test.

\section{HASIL PENELITIAN}

\section{Hasil Verfikasi Metode Pemeriksaan LDH}

Tabel. 1

Hasil Verifikasi Metode

Pemeriksaan LDH

\begin{tabular}{|c|c|c|c|c|}
\hline & $\begin{array}{c}\text { Bahan } \\
\text { Kontrol }\end{array}$ & Hasil & $\begin{array}{c}\text { Batas } \\
\text { Keberterimaan }\end{array}$ & Keterangan \\
\hline Presisi/CV & $\begin{array}{c}\text { Normal } \\
\text { Tinggi }\end{array}$ & $\begin{array}{l}1.9 \% \\
2,4 \%\end{array}$ & $7 \%$ & Diterima \\
\hline Akurasi/Bias & $\begin{array}{c}\text { Normal } \\
\text { Tinggi }\end{array}$ & $\begin{array}{l}0,41 \% \\
0,81 \%\end{array}$ & $4,3 \%$ & Diterima \\
\hline Tea & $\begin{array}{c}\text { Normal } \\
\text { Tinggi }\end{array}$ & $\begin{array}{l}4,21 \% \\
5,61 \%\end{array}$ & $11,4 \%$ & Diterima \\
\hline
\end{tabular}

Berdasarkan tabel 1 menunjukan bahwa presisi metode pemeriksaan LDH dari bahan kontrol normal sebesar 1,9\%, bahan kontrol high sebesar 2,4\% dan untuk akurasi bahan kontrol normal sebesar 0,41\%, bahan kontrol high sebesar 0,81\% serta TEa normal sebesar 4,21\% dan TEa high sebesar 5,61\%. Hasil uji presisi, akurasi dan TEa masih dalam batas yang diperbolehkan atau lebih kecil dari batas yang diperbolehkan. Pada hasil uji ini dapat diterima. 


\section{Karakteristik Subjek Penelitian}

Tabel. 2

Karakteristik Subjek Penelitian

\begin{tabular}{cccc}
\hline No. & Jenis Kelamin & Jumlah & Presentase \\
\hline 1 & Laki-laki & 6 & $20 \%$ \\
2 & Perempuan & 24 & $80 \%$ \\
& Total & 30 & $100 \%$ \\
\hline
\end{tabular}

Berdasarkan tabel 2 dapat diketahui bahwa kebanyakan yang menjadi subjek penelitian ini adalah jenis kelamin perempuan dengan jumlah 18 orang dengan presentase sebesar $90 \%$.

\section{Hasil Pemeriksaan Kadar LDH}

Tabel. 3

Hasil Pemeriksaan Kadar LDH dalam Serum

\begin{tabular}{lccc}
\hline \multicolumn{1}{c}{ Variabel } & Mean/Kadar Rata-rata & SD & p value \\
\hline $\begin{array}{l}\text { Centrifugasi 5 menit 3000 } \\
\text { rpm }\end{array}$ & 309,9 & 45,9 & \\
\cline { 1 - 1 } $\begin{array}{l}\text { Centrifugasi 3 menit 4400 } \\
\text { rpm }\end{array}$ & 306,4 & 37,3 & 0,478 \\
\hline
\end{tabular}

Berdasarkan tabel 3 hasil pengukuran kadar LDH darah serum yang disentrifugasi $3000 \mathrm{rpm} 5$ menit sebesar 309,9 U/L dan yang disentrifugasi $4400 \mathrm{rpm} 3$ menit sebesar 306,4 U/L. Hasil pengukuran ini kemudian diuji secara statistik menggunakan uji Paired $T$ - Test, diperoleh nilai p : 0,478 $(>0,05)$, artinya tidak ada perbedaan antara kadar LDH dalam serum yang disentrifugasi $3000 \mathrm{rpm} 5$ menit dan $4400 \mathrm{rpm} 3$ menit.

\section{PEMBAHASAN}

Sebelum dilakukan penelitian, metode dan alat terlebih dahulu telah dilakukan verifikasi dan pemantapan mutu internal. Hal ini untuk memastikan kehandalan metode pemeriksaan yang digunakan dalam penelitian. Selain dilakukan verifikasi metode, faktor-faktor yang memungkinkan terjadinya kesalahan atau gangguan saat pemeriksaan juga dihitung. Faktor-faktor yang memungkinkan terjadinya kesalahan atau eror dalam pemeriksaan dinyatakan sebagai nilai keberterimaan total eror (Allowable Total Error: $T E a$ ). TEa dihitung dengan menjumlahkan persentase bias dengan dua kali persentase CV. Batas nilai TEa ditentukan sebagai ukuran suatu metode bisa digunakan, selain menghitung presisi dan akurasi. CLIA (Clinical Laboratory Improvement Amendments) menuliskan batas TEa untuk metode pemeriksaan LDH adalah $<11,4 \%$. Nilai TEa yang diperoleh pada penelitian ini sebesar 4,21\% untuk kontrol normal dan 5,61\% untuk kontrol high. Hasil tersebut tidak melebihi TEa yang diperbolehkan. Hal ini membuktikan bahwa metode pemeriksaan LDH yang digunakan dalam penelitian ini dalam penelitian ini memang benar-benar layak digunakan (Lokhandwala et al., 2017).

Berdasarkan hasil penelitian yang diperoleh dapat dilihat bahwa tidak terdapat perbedaan hasil pengukuran kadar LDH pada sampel yang disentrifuse dengan waktu 5 menit dan kecepatan 3000 rpm, dengan waktu sentrifugasi 4400 rpm selama 3 menit. Hal 
ini sejalan dengan penelitian Minder dkk yang menyebutkan bahwa tidak terdapat perbedaan hasil pemeriksaan kadar LDH dengan menggunakan kecepatan dan waktu sentrifugasi.

Hal ini sejalan dengan penelitian yang telah dilakukan oleh Cadamuro et al., (2018) menunjukkan bahwa hasil penelitian tidak terdapat perbedaan yang signifikan pada pemeriksaan LDH dengan kecepatan sentrifugasi $2000 \mathrm{~g}$ (4230 rpm) selama 10 menit dan kecepatan sentrifugasi $3000 \mathrm{~g}(5180 \mathrm{rpm})$ selama 5 menit dan 7 menit. Hal ini dikarenakan sampel diperlakukan dengan meningkatkan kecepatan sentrifugasi dan mempersingkat waktu sentrifugasi begitu juga sebaliknya. Kecepatan dan waktu sentrifugasi masih sesuai dengan standar untuk mendapatkan serum yang tidak mengandung sel darah dan tidak hemolisis.

Salah satu faktor yang mempengaruhi kualitas serum adalah sentrifugasi. Sentrifugasi adalah teknik pemisahan cairan dari padatannya. Pada penelitian ini, sentrifugasi digunakan untuk memisahkan cairan dari padatan sel darah sehingga diperoleh serum. Sentrifugasi merupakan langkah pertama pada hampir semua prosedur fraksionasi atau penguraian sel yang digunakan untuk memisahkan endapan dari suatu suspensi dengan ukuran yang jauh berbeda (Brassard et al., 2018). Perbedaan serum dan plasma yang berada di dalam sel tidak boleh keluar sel agar tidak terjadi hemolisis yang dapat mempengaruhi hasil pemeriksaan. Selain hemolisis, sampel lipemik dan ikhterik dapat mengganggu pembacaan pada spektrofotometer (Ramadhani et al., 2019).

Tanpa mengurangi kualitas serum maka dilakukan pengurangan waktu sentrifugasi karena pemeriksaan Laktat Dehydrogenase (LDH) yang berada pada jantung dan hati perlu penanganan cepat sehingga hasil pemeriksaan juga dibutuhkan cepat. Lalu yang bisa dilakukan adalah mengurangi waktu sentrifugasi akan memberi dampak yang baik bagi laboratorium (Brassard et al., 2018).

Faktor-faktor yang mempengaruhi sentrifugasi antara lain kecepatan, waktu dan suhu. Semakin tinggi kecapatan sentrifugasi maka semakin sedikit pula waktu yang dibutuhkan untuk melakukan suatu putaran, hubungan tersebut berdasarkan dari hubungan yang berbanding terbalik antara suatu kecepatan dengan waktu gerak melingkar suatu sentrifugasi (Magnette et al., 2016).

Hasil penelitian juga menunjukkan bahwa penerapan gaya-g (gravitasi) tertentu atau kecepatan rotasi dengan sendirinya tidak memprediksi kemampuan pelet eksosom, dan waktu sentrifugasi yang berkepanjangan dapat mencapai hasil yang lebih besar dari RNA dan protein eksosomal, sedangkan waktu sentrifugasi yang sangat lama menghasilkan konsentrasi protein yang berlebihan dalam pelet eksosom.

Perlunya memperhatikan pemantapan mutu internal dalam laboratorium sebelum melakukan pemeriksaan terhadap suatu sampel. Hal ini harus dilakukan oleh laboratorium itu sendiri dan dilakukan secara terus menerus setiap hari guna mengurangi kejadian penyimpangan terhadap suatu hasil pemeriksaan sehingga diperoleh hasil pemeriksaan yang dapat dipercaya.

Sehubungan dengan pengurangan waktu akan didapat juga manfaat lain dari aspek ekonomi yaitu penghematan listrik sehingga biaya dari suatu laboratorium tersebut dapat berkurang. Dampak pengurangan waktu sentrifugasi dapat memperlambat penurunan produktifitas atau kinerja sentrifus akibat penggunaan yang terlalu lama sehingga fungsi alat tersebut menurun. 


\section{SIMPULAN}

Tidak terdapat perbedaan kadar LDH dalam serum dari darah yang disentrifugasi 3000 rpm selama 5 menit dan 4400 rpm selama 3 menit.

\section{SARAN}

Disarankan untuk melakukan sentrifugasi $4400 \mathrm{rpm}$ selama 3 menit pada pemeriksaan LDH untuk mempersingkat waktu dan menghemat biaya listrik.

\section{DAFTAR PUSTAKA}

Brassard, D., Clime, L., Daoud, J., Geissler, M., Malic, L., Charlebois, D., \& Veres, T. (2018). Microfluidic-Based Platform for Universal Sample Preparation and Biological Assays Automation for Life-Sciences Research and Remote Medical Applications. Deep Space Gateway Science Workshop 2018

Cadamuro, J., Mrazek, C., Leichtle, A. B., Kipman, U., Felder, T. K., Wiedemann, H., \& Haschke-Becher, E. (2018). Influence of Centrifugation Conditions on the Results of 77 Routine Clinical Chemistry Analytes using Standard Vacuum Blood Collection Tubes and the New BD-Barricor Tubes. Biochemia Medica, 28(1), 010704. https://doi.org/10.11613/BM.2018.010704

Eid-Lidt, G., Reyes, J., Rivera, A., Limon, C., Soto, M., \& Gaspar, J. (2019). TCT-777 Prevention of Radial Artery Occlusion: Comparison of 3 Hemostatic Methods in Transradial Intervention. Journal of the American College of Cardiology, 74(13), B761. DOI: 10.1016/j.jacc.2019.08.920

Ghani, L., Susilawati, M. D., \& Novriani, H. (2016). Faktor Risiko Dominan Penyakit Jantung Koroner di Indonesia. Buletin Penelitian Kesehatan, 44(3). https://doi.org/10.22435/bpk.v44i3.5436.153-164

Gressner, A. M., \& Gressner, O. A. (2017). International Federation of Clinical Chemistry and Laboratory Medicine. Lexikon der Medizinischen Laboratoriumsdiagnostik. https://doi.org/10.1007/978-3-662-49054-9_1601-1

Hermayanti, D., \& Nursiloningrum, E. (2018). Hiperglikemia pada Anak dengan Diagnosis Diabetes Mellitus Type-1, Diferential Diagnostic Maturity Onset Diabetes of The Young (Mody). Saintika Medika, 14(2). https://doi.org/10.22219/sm.vol14.smumm2.7162

Kemenkes RI. (2019). Info Datin Situasi Kesehatan Jantung. Journal of Chemical Information and Modeling. https://doi.org/10.1017/CBO9781107415324.004

Lippi, G., Mattiuzzi, C., \& Bovo, C. (2018). Are we Getting Better at the Preanalytical Phase or Just Better at Measuring it? Journal of Laboratory and Precision Medicine, 3, 11. https://doi.org/10.21037/jlpm.2018.01.03

Lokhandwala, P. M., Riel, S. L., Haley, L., Lu, C., Chen, Y., Silberstein, J., \& Eshleman, J. R. (2017). Analytical Validation of Androgen Receptor Splice Variant 7 Detection in a Clinical Laboratory Improvement Amendments (CLIA) Laboratory Setting. Journal of Molecular Diagnostics, 18(1), 115-125. https://doi.org/10.1016/j.jmoldx.2016.08.003

Magnette, A., Chatelain, M., Chatelain, B., Ten Cate, H., \& Mullier, F. (2016). PreAnalytical Issues in the Haemostasis Laboratory: Guidance for the Clinical Laboratories. Thrombosis Journal, 14(1). https://doi.org/10.1186/s12959-016-0123$\mathrm{Z}$ 
Ramadhani, Q. A., Garini, A., Nurhayati, N., \& Harianja, S. H. (2019). Perbedaan Kadar Glukosa Darah Sewaktu Menggunakan Serum dan Plasma Edta. JPP (Jurnal $\begin{array}{llll}\text { Kesehatan Poltekkes } \quad \text { Palembang), } & \text { 14(2), }\end{array}$ https://doi.org/10.36086/jpp.v14i2.407

Schneider, F., Maurer, C., \& Friedberg, R. C. (2017). International Organization for Standardization (ISO) 15189. Annals of Laboratory Medicine, 37(5), 365-370. https://doi.org/10.3343/alm.2017.37.5.365

Schneider, S. A., \& Alcalay, R. N. (2017). Neuropathology of Genetic Synucleinopathies with Parkinsonism: Review of the literature. Movement Disorders, 32(11), 15041523. https://doi.org/10.1002/mds.27193 